\title{
Conservation of threatened plant species in botanic garden reserves in Brazil
}

\author{
Maria Lúcia M. N. da Costa, Peter Wyse Jackson \\ Ricardo Avancini Fernandes and Ariane Luna Peixoto
}

\begin{abstract}
Over the last few decades botanic gardens worldwide have been encouraged to adopt complementary measures for the conservation of plant species from their own regions, combining in situ conservation efforts with ex situ methods, both in cultivation and in storage. This integrated approach is particularly important for botanic gardens in the tropics, which face the challenge of conserving a highly diverse and often threatened flora. We gathered information on the occurrence of threatened species in the natural vegetation reserves of 21 Brazilian botanic gardens. The data were collected from herbarium records in the database of the National Centre for Flora Conservation, and from the available plant inventories of these reserves. The results indicate that 148 species from the List of Threatened Species of Brazilian Flora are recorded as having been collected in the reserves. Of these, 51 species were maintained in the living collections of 18 botanic gardens and 83 species were recorded in federally protected areas. The occurrence of threatened species in the reserves of botanic gardens highlights the scientific value of these areas, as well as their biological, social and cultural importance for conservation. The results may be used to inform the planning of integrated conservation strategies for threatened species.
\end{abstract}

Keywords Botanic garden, conservation, ex situ, flora, in situ, plant, threatened species

Supplementary material for this article can be found at https://doi.org/10.1017/So030605316000776

\section{Introduction}

Changes in the understanding of plant conservation have been influenced by the development of interrelationships between conservation and sustainable use, the adoption of the concept of biodiversity, and advances in conservation biology (Heywood \& Iriondo, 2003). The Convention on Biological Diversity has given rise to many

Maria Lúcia M. N. DA Costa (Corresponding author), RiCardo AvancinI Fernandes and Ariane Luna Peixoto Instituto de Pesquisas Jardim Botânico do Rio de Janeiro, R. Pacheco Leão 940. Cep 22430-060, Rio de Janeiro, Rio de Janeiro, Brazil. E-mail mcosta@jbrj.gov.br

Peter Wyse Jackson Missouri Botanical Garden, St Louis, Missouri, USA

Received 12 February 2016. Revision requested 8 March 2016.

Accepted 5 July 2016. First published online 28 November 2016. national and international commitments, which have stimulated the adoption of new approaches in response to increasing environmental threats.

Some countries have developed national targets and programmes to address the objectives of the Global Strategy for Plant Conservation (adopted by the Convention on Biological Diversity in 2002, and updated in 2010 for 2011-2020) but although significant advances have been made worldwide, efforts need to be intensified if the targets are to be achieved (Wyse Jackson \& Kennedy, 2009). As scientific institutions, botanic gardens have a unique opportunity to contribute to the Global Strategy for Plant Conservation, through their work on the documentation, research and preservation of plant diversity, while simultaneously undertaking educational activities to mobilize public responses to global environmental change (Blackmore et al., 2011). These institutions have diverse facilities and staff to conduct research in plant taxonomy, horticulture, conservation biology, ecological restoration and genetics. The establishment of partnerships with other institutions at local, national and international levels facilitates and supports broader involvement in other areas of science.

The update of the Global Strategy for Plant Conservation brought new challenges, especially for countries with high biodiversity, and drew attention to the importance of plant diversity for human well-being and in addressing poverty (SCBD, 2010). As a consequence, increased engagement of botanic gardens in the conservation and sustainable use of biodiversity is needed. Linking plant conservation with sustainable use of plants and their natural habitats by local communities has therefore been increasingly recognized as an important priority. Tropical botanic gardens have been encouraged to invest expertise in implementing in situ conservation management programmes, including monitoring, restoration, education and policy involvement (Chen et al., 2009; Crane et al., 2009).

Brazilian botanic gardens face specific challenges, considering that there are $>46$,0oo known plant species in Brazil, including a high number of endemic species (Zappi et al., 2015). This diversity has been affected by urbanization and agricultural expansion, which are both considered to be major causes of habitat destruction and species extinction in Brazil (Brandon et al., 2005). The List of Threatened Species of Brazilian Flora (hereafter referred to as the national Red List; Ministério do Meio Ambiente, 2014) includes 2,113 species, categorized according to the IUCN criteria (IUCN, 2001). The national Red List is based on the assessment of 
4,617 plant species, representing only c. $10 \%$ of the known Brazilian flora. As the assessment process continues it is likely that the number of species listed as threatened will increase significantly. Regional lists of threatened species have been developed for only seven of Brazil's 27 states: Santa Catarina (Klein, 1990), Paraná (Hatschbach \& Ziller, 1996), Minas Gerais (COPAM, 1997), Rio Grande do Sul (Rio Grande do Sul, 2003), Pará (COEMA, 2007), São Paulo (São Paulo, 2004) and Espírito Santo (Espírito Santo, 2005).

A great asset of botanic gardens in Brazil is their maintenance of areas of natural vegetation, which potentially facilitate the implementation of activities focused on in situ conservation. We gathered information about the reserves of Brazil's botanic gardens and assessed the occurrence of threatened species in these areas. The results may form the basis of in situ conservation guidelines for botanic gardens in Brazil, building on recommendations included in the Action Plan for Brazilian botanic gardens (Pereira et al., 2004).

\section{Methods}

A questionnaire was submitted to 36 botanic gardens (RBJB, 2011) in 2011-2012, to gather information regarding the maintenance of areas of natural vegetation within or associated with each botanic garden, hereafter referred to as reserves. The botanic gardens were asked to provide information on the size of the reserve, the biome, the dominant vegetation types, and whether plant inventories of the areas had been undertaken.

Data on threatened species in each reserve were assembled from the database of the National Centre for Flora Conservation (CNCFlora, 2013). This system compiles herbarium records from SpeciesLink (2010) and the Global Biodiversity Information Facility (GBIF, 2010), comprising $>4,600$ species from national, state and international red lists. All the records have been confirmed by taxonomists and the database contains the accepted species names and valid synonyms in accordance with the list of Brazilian Flora (Lista da Flora do Brasil, 2010).

The assessment of threatened species from the national Red List and seven state lists recorded in the botanic garden reserves was performed by applying a filter in the database, using the state, municipality, locality, name and acronym of reserves as keywords. Any existing plant inventories from these reserves were also reviewed, comparing species listed in the inventories with the threatened species recorded in the CNCFlora database. All the data assessed were recorded in a database.

An additional survey of the ex situ collections of the botanic gardens was undertaken. Gardens were asked which threatened species from the national Red List were maintained in their ex situ collections. The data were consolidated and compared with the list of species recorded in the botanic garden reserves.

\section{Results}

Of the 26 botanic gardens that responded to the questionnaire, 21 indicated that they maintained a reserve within or beyond their boundaries (Fig. 1). This included those where the management of protected areas is undertaken in association with other institutions. Data on the area of the reserves, and their vegetation types and biomes are presented in Table 1.

The majority of botanic gardens mentioned that surveys on the floristic composition of reserves under their management had been undertaken. Some have not been published; others have been reported in theses (Barbosa, 1996; Weiser, 2007; Miachir, 2009), dissertations (Pinheiro, 2000; Sousa-Júnior, 2006; Matos, 2007; Felix, 2009; Silva, 2010), graduation monographs and books (Cervi et al., 1989; Lisboa, 2002) and articles (Bueno \& Martins, 1986; Thomaz \& Monteiro, 1997; Marquete et al., 2001; Nóbrega \& Prado, 2008). Some studies were conducted as part of university research programmes and $<50 \%$ were carried out by the staff of the botanic gardens.

One hundred and forty eight of the threatened species that have been collected in these reserves are on the national Red List, representing $7 \%$ of the entire list (Supplementary Table $\mathrm{S}_{1}$ ). These species represent 43 families and 110 genera. Species of Orchidaceae (28), Bromeliaceae (14) and Myrtaceae (10) were the most frequently recorded. The records of these 148 species were distributed amongst 15 reserves, the majority (11) of which are located in the Atlantic Forest region, with three in the Cerrado and one in the Amazon (Table 1). The majority of species $(n=124$, $84 \%$ ) were recorded in only a single reserve, with a smaller percentage collected in two $(n=17,11 \%)$, three $(n=6,4 \%)$ or five reserves $\left(n=1,1 \%\right.$; Supplementary Table $\left.S_{1}\right)$.

Of the 148 threatened species, $18(12 \%)$ are categorized as Critically Endangered, 78 (53\%) are Endangered and 52 $(35 \%)$ are Vulnerable. Many are endemic to the Atlantic Forest $(n=126,85 \%)$ or to a particular state $(n=59,40 \%)$, mainly states in the south-east. The state of Espírito Santo has the largest number of endemic and threatened species (35) recorded in botanic garden reserves, followed by São Paulo (13).

Of the 148 threatened species recorded in the reserves, 51 were also cultivated in living collections of 18 botanic gardens (Supplementary Table S1). This group includes one species categorized as Critically Endangered, 26 Endangered and 24 Vulnerable species. The most frequently recorded families amongst these living plant records were Orchidaceae (12 species) and Bromeliaceae (10 species). Twenty-three species 


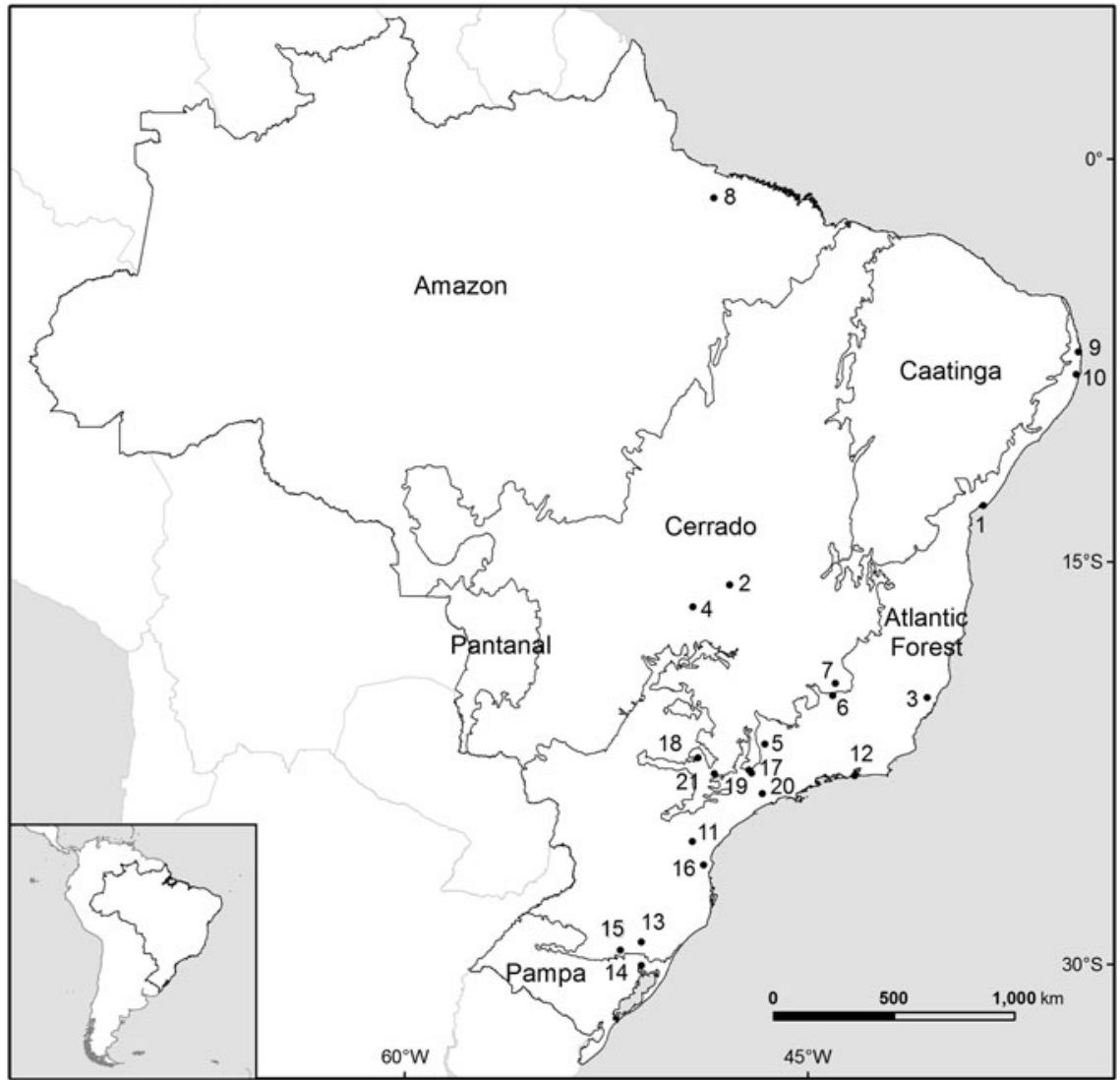

FIG. 1 Geographical distribution, by biome, of 21 Brazilian botanic gardens (numbers in Table 1) that maintain areas of natural vegetation.
(45\%) were recorded in a single living collection and also in a single reserve. Euterpe edulis accounted for the largest number of records in both the living collections (12) and the reserves (5).

A comparison of data from this study with data on the occurrence of threatened species in federally protected areas (CNCFlora, 2016) showed that of the 148 species 35 have been recorded simultaneously in the living collections, the reserves and federally protected areas. The number of species recorded exclusively in the reserves of botanic gardens was 49 (Supplementary Table S1).

The number of threatened species from the seven state Red Lists recorded in the botanic garden reserves was 527. This number does not take into account species on the national Red List. These 527 species represent 113 families and 314 genera. Orchidaceae (78), Bromeliaceae (50) and Myrtaceae (36) were the most frequently recorded families. The records of these species are from 20 reserves, 15 of which are located in states with Red Lists (Table 1). Most of the 527 species $(n=334,63 \%)$ have been recorded in only a single reserve.

\section{Discussion}

The data presented here were derived largely from online herbarium records and to a lesser extent from floristic inventories of the reserves. However, some of these inventories are limited in scope. Only a few studies have focused on entire reserves (e.g. the inventory of Parque Estadual Fontes do Ipiranga, published in the journal Hoehnea during 1981-2001); others are incomplete or limited to particular taxonomic groups (Nóbrega \& Prado, 2008). Some inventories were undertaken as part of university studies, illustrating the importance of partnerships to overcome the shortage of human resources and expertise in some Brazilian botanic gardens.

Many of the inventory data reviewed are not available digitally. There is an urgent need to record and integrate data on the occurrence of plants in living collections, herbaria and reserves, using geographical information systems. Botanic gardens play an important role in the dissemination of such data, which are fundamental to comprehensive studies of species distribution and for identification of important areas for conservation.

The reserve located in the Amazon biome contrasts in size and number of species with those in the Atlantic Forest. Compared to other biomes the Amazon has the largest protected areas and the largest percentage of protected area in the country (IBGE, 2012a). Most of the $12 \%$ of Atlantic Forest remaining exists in small fragments and there is therefore a high degree of fragmentation (Ribeiro et al., 2009). The majority (86\%) of botanic garden reserves located in this biome occupy $<100$ ha. However, small 
TABLE 1 Reserves managed by botanic gardens in Brazil (Fig. 1), with \% of total area of botanical garden, biome (area of reserve), vegetation type, no. of threatened species on the national Red List recorded in the reserve, and no. of threatened species on state Red Lists recorded in the reserve.

\begin{tabular}{|c|c|c|c|c|c|c|c|}
\hline No. & State & Botanic garden (Reserve designation) & $\begin{array}{l}\% \text { of botanical } \\
\text { garden area }\end{array}$ & $\begin{array}{l}\text { Biome (area of } \\
\text { reserve, ha) }\end{array}$ & $\begin{array}{l}\text { Vegetation type } \\
\text { (IBGE, 2012b) }\end{array}$ & $\begin{array}{l}\text { No. of threatened } \\
\text { species from na- } \\
\text { tional Red List }\end{array}$ & $\begin{array}{l}\text { No. of threatened spe- } \\
\text { cies from state Red Lists } \\
\text { (No. from the list of the } \\
\text { state where the reserve } \\
\text { is located) }\end{array}$ \\
\hline 1 & Bahia & Jardim Botânico de Salvador (Reserve) & 94 & Atlantic Forest (16) & $\begin{array}{l}\text { Floresta Ombrófila } \\
\text { Densa }\end{array}$ & 2 & 3 \\
\hline 2 & $\begin{array}{l}\text { Distrito } \\
\text { Federal }\end{array}$ & Jardim Botânico de Brasília (Estação Ecológica) & 96 & Cerrado $(4,800)$ & Savannah (Cerrado) & 4 & 55 \\
\hline \multirow[t]{3}{*}{3} & Espírito Santo & Museu de Biologia Prof. Mello Leitão (Reserve) & 61 & Atlantic Forest (5) & $\begin{array}{l}\text { Floresta Ombrófila } \\
\text { Densa }\end{array}$ & & $54(24)$ \\
\hline & & Estação Biológica da Caixa d’Água & * & Atlantic Forest (21) & $\begin{array}{l}\text { Floresta Ombrófila } \\
\text { Densa }\end{array}$ & 13 & \\
\hline & & Estação Biológica de Santa Lúcia & * & Atlantic Forest (52) & $\begin{array}{l}\text { Floresta Ombrófila } \\
\text { Densa }\end{array}$ & 74 & $211(91)$ \\
\hline 1 & Goiás & $\begin{array}{l}\text { Jardim Botânico Amália Hermano Teixeira } \\
\text { (Reserve) }\end{array}$ & 77 & Cerrado (72) & $\begin{array}{l}\text { Floresta Estacional } \\
\text { Semidecidual }\end{array}$ & & \\
\hline 5 & Minas Gerais & $\begin{array}{l}\text { Fundação Jardim Botânico de Poços de Caldas } \\
\text { (Reserve) }\end{array}$ & 33 & Atlantic Forest (15) & $\begin{array}{l}\text { Floresta Estacional } \\
\text { Semidecidual }\end{array}$ & & \\
\hline 5 & Minas Gerais & $\begin{array}{l}\text { Jardim Botânico da Fundação Zoobotânica de } \\
\text { Belo Horizonte (Reserve) }\end{array}$ & 41 & $\begin{array}{l}\text { Atlantic Forest/ } \\
\text { Cerrado (60) }\end{array}$ & $\begin{array}{l}\text { Floresta Estacional } \\
\text { Semidecidual; } \\
\text { Savannah (Cerrado) }\end{array}$ & & $5(2)$ \\
\hline 7 & Minas Gerais & $\begin{array}{l}\text { Museu de Historia Natural e Jardim Botânico da } \\
\text { Universidade Federal de Minas Gerais (Reserve) }\end{array}$ & 99 & Atlantic Forest (60) & $\begin{array}{l}\text { Floresta Estacional } \\
\text { Semidecidual }\end{array}$ & 3 & $6(0)$ \\
\hline \multirow[t]{2}{*}{8} & Pará & $\begin{array}{l}\text { Museu Paraense Emilio Goeldi e Parque } \\
\text { Zoobotânico }\end{array}$ & & & & & \\
\hline & & Estação Científica Ferreira Penna & * & Amazon $(33,000)$ & $\begin{array}{l}\text { Floresta Ombrófila } \\
\text { Densa, Floresta } \\
\text { Ombrófila Aberta }\end{array}$ & 3 & $12(2)$ \\
\hline 9 & Paraíba & Jardim Botânico Benjamin Maranhão (Reserve) & 99 & $\begin{array}{l}\text { Atlantic Forest } \\
(343)\end{array}$ & $\begin{array}{l}\text { Floresta Estacional } \\
\text { Semidecidual }\end{array}$ & 2 & 24 \\
\hline 10 & Pernambuco & Jardim Botânico do Recife (Reserve) & 91 & Atlantic Forest (10) & $\begin{array}{l}\text { Floresta Ombrófila } \\
\text { Densa }\end{array}$ & 3 & 15 \\
\hline 11 & Paraná & $\begin{array}{l}\text { Jardim Botânico Municipal Francisca Maria } \\
\text { Garfunkel Rischbieter (Reserve) }\end{array}$ & 40 & Atlantic Forest (7) & $\begin{array}{l}\text { Floresta Ombrófila } \\
\text { Mista (Floresta de } \\
\text { Araucária) }\end{array}$ & 3 & $19(4)$ \\
\hline 12 & Rio de Janeiro & $\begin{array}{l}\text { Instituto de Pesquisas Jardim Botânico do Rio de } \\
\text { Janeiro (Reserve) }\end{array}$ & 59 & Atlantic Forest (85) & $\begin{array}{l}\text { Floresta Ombrófila } \\
\text { Densa }\end{array}$ & 13 & 69 \\
\hline
\end{tabular}


nature reserves can play an important role in landscape connectivity and biodiversity conservation in areas subjected to anthropogenic pressure.

The largest number of threatened species, whether at the national or state level, were recorded in reserves in the Atlantic Forest. This biome has $>15,000$ recorded species of Angiosperms, with 49.5\% endemism (BFG, 2015), and the largest number of threatened species of any Brazilian biome (Ministério do Meio Ambiente, 2014). The large number of species assessed in the Atlantic Forest is attributable to the high concentration of research institutions, taxonomists and online herbarium collections in the south-east (Martinelli et al., 2013); for example, the Estação Biológica de Santa Lúcia, located in an area of Atlantic Forest in Espírito Santo state, has the largest number of records of threatened species (74 from the national Red List and 211 from state lists). This area is known for its high level of biodiversity, and there has been intensive collection of plant records there (Thomaz \& Monteiro, 1997; Mendes \& Padovan, 2000; Murray-Smith et al., 2009; Saiter et al., 2011).

The records of threatened and endemic species in the reserves studied highlight the scientific value of these areas, as well as their biological, social and cultural importance for conservation. Additionally, they provide an opportunity for botanic gardens to implement conservation strategies that focus on the local threatened flora (BGCI, 2012). This should be a strategic goal for all of these botanic gardens.

However, the presence of a species in a protected area does not guarantee its conservation (Heywood \& Iriondo, 2003). Research on population dynamics, phenology and regeneration is required to understand the local behaviour and population biology of threatened species and to inform proposals of suitable management measures. Procedures to address threats to the environment and to evaluate the effectiveness of conservation management regimes are also recognized as being important (Willis \& Morkel, 2008; Havens et al., 2014). Furthermore, it will be necessary to assess potential impacts of climate change on threatened species in reserves. It is unclear whether many threatened plant species will have the resilience or adaptive potential to survive future changes in environmental conditions, especially given the diminishing possibility of natural migration to more favourable areas as protected areas become increasingly isolated. Another area for potential research is the genetic variation within plant populations. Currently we do not know the extent to which the genetic diversity of most threatened plant species is contained within the surviving populations in protected areas, or in their living collections, and research on this aspect of their conservation biology could help determine future management practices and procedures. This knowledge is essential for setting out effective conservation actions suitable for each species.

The botanic gardens of Brazil are faced with the challenge of broadening their remit beyond their traditional role in ex situ conservation, to more effectively conserve a diverse and often threatened flora. Their importance is evident from the diversity of their holdings of threatened species. Botanic gardens can enhance their in situ conservation actions by increasing the number and size of reserves they manage as well as by carrying out studies on ecological restoration and species reintroduction. Restoration ecology has not yet become a common practice among Brazilian botanic gardens, although some initiatives have been undertaken, such as the planting of 57 native species in an area of degraded riparian Atlantic Forest in the Jardim Botânico do Rio de Janeiro (T.S. Pereira, pers. comm., 2016) and enrichment planting of Euterpe edulis in Parque Estadual das Fontes do Ipiranga (Aguiar et al., 2011).

Through their maintenance of areas of natural vegetation, botanic gardens are well-placed to adopt complementary measures for both in situ and ex situ conservation of plant species. The reserves can provide plant material for studies on germination, storage, cultivation and propagation, and also to improve the genetic diversity of collections. Ex situ collections must be managed to the highest standards, to provide resources to support species recovery in the wild (Maunder et al., 2004; Rae, 2011). The data presented here may assist the establishment of a collection plan for material for these purposes. However, further surveys on the floristic composition of these areas are required if their potential to support exemplary botanic garden research programmes is to be achieved. Strategic partnerships with in situ conservation and research organizations can be of significant help in promoting the conservation work of botanic gardens.

Priorities for species conservation may be determined by considering criteria such as extinction threat, endemism, and presence or absence in ex situ collections and protected areas. We showed that 49 threatened species were recorded exclusively in botanic garden reserves, with no records in any living collections or other protected areas. Among them are 16 Critically Endangered species, 15 of which are endemic to a single state. We consider that these species should receive priority attention, especially from the botanic gardens in the regions in which they occur.

Species of economic importance, such as Euterpe edulis (palmito), Cedrela fissilis (cedro rosa) and Caesalpinia echinata (pau brasil), which occur frequently in collections, reserves of botanic gardens, and protected areas, nevertheless play important roles as flagship species. They can help to drive conservation efforts for other threatened plants. Species of Bromeliaceae and Orchidaceae that are known for their ornamental value and commercial use could be used to stimulate the development of integrated national or regional plans (incorporating measures to coordinate actions, define responsibilities, identify centres of expertise, optimize financial resources, avoid duplicating efforts and improve effectiveness of conservation measures). 
The majority of the reserves managed by the botanic gardens of Brazil encompass remnants of natural or seminatural vegetation in urban centres. Considering ongoing urbanization, such areas are of increasing importance as biodiversity reserves, refuges for species of local fauna and flora, and providers of ecosystem services (Alvey, 2006; Jim \& Chen, 2009; Ward et al., 2010). Urban green spaces are also important socially and culturally (Oldfield, 2008). Small urban forest reserves, such as those maintained by botanic gardens, have a crucial role in spreading conservation messages, which could help to mitigate human pressure on natural areas (Pinheiro et al., 2006). Some botanic gardens are popular tourist attractions (e.g. Jardim Botânico do Rio de Janeiro receives c. 1 million visitors annually; JBRJ, 2015). The social benefits from natural areas associated with botanic gardens may be enhanced by the associated capacity, resources and experience of the botanic gardens. These reserves should be included in visitation routes, with guided tours, nature trails and appropriate interpretation. Botanic gardens can thus offer visitors a unique experience and increase the audience for conservation messages.

Although this study does not represent a complete inventory of the reserves maintained by Brazil's botanic gardens, it nevertheless provides the first compilation of information on the presence of threatened plant species in these areas, demonstrating their value and significance. The consolidated data will be made available for inclusion in accessible integrated information systems in Brazil, such as that of CNCFlora (2013) and botanical garden databases, and will be used to inform and guide conservation actions and future recovery work for threatened plant species.

\section{Acknowledgements}

We thank all the staff of the botanic gardens that contributed to this survey, and Ernani Bellon for his help with map creation. We gratefully acknowledge the comments and suggestions received from two anonymous reviewers and from Martin Fisher.

\section{Author contributions}

MLMNC designed the study, analysed data and wrote the article. PWJ wrote and revised the article. RAF conducted database analysis. ALP supervised the design and development of the study, and helped evaluate the article.

\section{References}

Aguiar, F.F.A., Cerati, T.M., Carvalho, C.P., Young, J.L.M. \& Aguiar, J. (2011) Enriquecimento de uma trilha com Euterpe edulis Mart. no Jardim Botânico de São Paulo como estratégia de educação e conservação. In $1^{\circ}$ Congresso de Áreas Verdes. (ed. Secretaria
Municipal do Verde e do Meio Ambiente), pp. 216-218. São Paulo, Brazil.

Alvey, A.A. (2006) Promoting and preserving biodiversity in the urban forest. Urban Forestry \& Urban Greening, 5, 195-201.

B ARbosa, M.R.V. (1996) Estudo florístico e fitossociológico da Mata do Buraquinho, remanescente de Mata Atlântica em João Pessoa, Paraíba. PhD thesis. Universidade Estadual de Campinas, Brazil.

BFG (The Brazil Flora Group) (2015) Growing knowledge: an overview of seed plant diversity in Brazil. Rodriguésia, 66, 1085-1113. BGCi (Botanic Gardens Conservation International) (2012) International Agenda for Botanic Gardens in Conservation. Botanic Gardens Conservation International, Richmond, UK.

Blackmore, S., Gibby, M. \& Rae, D. (2011) Strengthening the scientific contribution of botanic gardens to the second phase of the Global Strategy for Plant Conservation. Botanical Journal of the Linnean Society, 166, 267-281.

Brandon, K., Fonseca, G.A.B., Rylands, A.B. \& Silva, J.M.C. (2005) Conservação brasileira: desafios e oportunidades. Megadiversidade, 1, 7-13.

Bueno, O.L. \& Martins, S.M.A. (1986) A flora e vegetação espontânea do Jardim Botânico de Porto Alegre, RS, Brasil. Fanerógamas herbáceas e arbustivas. Iheringia Série Botânica, 35, 5-23.

Cervi, A.C., Paciornik, E.F., Vieira, R.F. \& Marques, L.C. (1989) Espécies vegetais de um Remanescente de Floresta de Araucária (Curitiba, Brasil). Estudo preliminar I. Acta Biológica Paranaense, 18, 73-114.

Chen, J., CAnnon, C.H. \& Hu, H. (2009) Tropical botanical gardens: at the in situ ecosystem management frontier. Trends in Plant Science, 14, 584-589.

CNCFlora (2013) Centro Nacional de Conservação da Flora. Http:// cncflora.jbrj.gov.br/portal [accessed 8 April 2013].

CNCFlora (2016) Espécies Ameaçadas da Flora em UCs Federais. Http://ckan.jbrj.gov.br/dataset/ameacadas-em-ucs-federais [accessed 22 April 2016].

COEma (Conselho Estadual de Meio Ambiente) (2007) Resolução n ${ }^{\circ} 54$ de 24/10/2007. Http://www.sema.pa.gov.br/2007/10/ 24/10059/ [accessed 26 October 2013].

Copam (Conselho Estadual de Política Ambiental de Minas Gerais) (1997) Deliberação COPAM nº 085 de 1997. Http:// www.siam.mg.gov.br/sla/download.pdf?idNorma $=5483$ [accessed 10 September 2013].

Crane, P.R., Hopper, S.D., Raven, P.H. \& Stevenson, D.W. (2009) Plant science research in botanic gardens. Trends in Plant Science, $14,575-577$.

Espírito Santo (2005) Decreto $n^{\circ} 499-\mathrm{R}$ de 13 de junho de 2005. Declara as espécies da fauna e flora silvestres ameaçadas de extinção no Estado do Espírito Santo, Brazil.

Felix, D.F. (2009) Composição florística do Museu de História Natural e Jardim Botânico da Universidade Federal de Minas Gerais. MSc thesis. Universidade Federal de Minas Gerais, Belo Horizonte, Brazil.

Flora do Brasil 2020 em Construção (2016) Jardim Botânico do Rio de Janeiro. Http://floradobrasil.jbrj.gov.br/ [accessed 2 May 2016].

GBIF (Global Biodiversity Information Facility) (2010) Http://gbif. org/ [accessed 3 September 2010].

Hatsснвасн, G.G. \& Ziller, S.R. (1996) Lista vermelha de plantas ameaçadas de extinção no Estado do Paraná. SEMA/GTZ, Curitiba, Brazil.

Havens, K., Kramer, A.T. \& Guerrant, Jr, E.O. (2014) Getting plant conservation right (or not): the case of the United States. International Journal of Plant Sciences, 175, 3-10.

Heywood, V.H. \& Iriondo, J.M. (2003) Plant conservation: old problems, new perspectives. Biological Conservation, 113, 321-335. 
IBGE (Instituto Brasileiro de Geografia e Estatística) (2012a) Indicadores de desenvolvimento sustentável - Brasil 2012. Http://www.ibge.gov.br/home/geociencias/recursosnaturais/ids/ default_2012.shtm [accessed 24 April 2013].

ibGE (Instituto Brasileiro de Geografia e Estatística) (2012b) Manual técnico da vegetação brasileira. Instituto Brasileiro de Geografia e Estatística, Rio de Janeiro, Brazil.

IUCN (2001) IUCN Red List Categories and Criteria. Version 3.1. Http://www.iucnredlist.org [accessed 2 April 2011].

JBRJ (Jardim Botânico do Rio de Janeiro) (2015) Relatório de Gestão 2015. Instituto de Pesquisas Jardim Botânico do Rio de Janeiro, Rio de Janeiro, Brazil.

Jim, C.Y. \& Chen, W.Y. (2009) Ecosystem services and valuation of urban forests in China. Cities, 26, 187-194.

KLEIN, R.M. (1990) Espécies raras ou ameaçadas de extinção do estado de Santa Catarina. IBGE, Diretoria de Geociências, Rio de Janeiro, Brazil.

LisboA, P.L.B. (ed.) (2002) Caxiuanã: populações tradicionais, meio físico e diversidade biológica. Museu Paraense Emílio Goeldi. Belém, Brazil.

Lista da Flora do Brasil (2010) Lista de Espécies da Flora do Brasil. Http://floradobrasil.jbrj.gov.br/ [accessed 25 October 2010].

Marquete, R., Valente, M.C., Silva, N.M.F., Guimarães, E.F., Marquete, O., Giordano, L.C.S. et al. (2001) Checklist das espécies ocorrentes nas áreas do entorno do Instituto de Pesquisas Jardim Botânico do Rio de Janeiro - Pteridófitas e Angiospermas. Bradea, 8, 227-258.

Martinelli, G., Valente, A.S.M., Maurenza, D., Kutschenko, D.C., Judice, D.M., Silva, D.S. et al. (2013) Avaliações de risco de extinção de espécies da flora brasileira. In Livro Vermelho da Flora Brasileira (eds G. Martinelli \& M.A. Moraes), pp. 6o-84. Andrea Jakobson Estúdio e Instituto de Pesquisas Jardim Botânico do Rio de Janeiro, Brazil.

Matos, W.R. (2007) Composição florística e estrutura de um trecho de floresta urbana, nos contrafortes do Maciço da Tijuca. MSc thesis. Universidade Federal do Rio de Janeiro, Brazil.

Maunder, M., Havens, K., Guerrant, Jr, E.O. \& Falk, D.A. (2004) Ex situ methods: a vital but underused set of conservation resources. In Ex Situ Plant Conservation: Supporting Species Survival in the Wild (eds E.O. Guerrant Jr, K. Havens \& M. Maunder), pp. 3-20. Island Press, Washington, DC, USA.

Mendes, S.L. \& Padovan, M.P. (200o) A Estação Biológica de Santa Lúcia, Santa Teresa, Espírito Santo. Boletim do Museu de Biologia Mello Leitão, 11/12, 7-34.

Miachir, J.I. (2009) Caracterização da vegetação remanescente visando à conservação e restauração florestal no município de Paulínia - SP. $\mathrm{PhD}$ thesis. Universidade de São Paulo, Piracicada, Brazil.

Ministério do Meio Ambiente (2014) Portaria MMA n ${ }^{\circ} 443$ de 17 de dezembro de 2014. In Diário Oficial da União. 18 de dezembro de 2014, n 245, Seção 1. pp. 110-121.

Murray-Smith, C., Brummitt, N., Oliveira-Filho, A.T., Bachman, S., Moat, J., Lughadha, E.N. \& Lucas, E.J. (2009) Plant diversity hotspots in the Atlantic coastal forests of Brazil. Conservation Biology, 23, 151-163.

Nóbrega, G.A. \& Prado, J. (2008) Pteridófitas da vegetação nativa do Jardim Botânico Municipal de Bauru, Estado de São Paulo, Brasil. Hoehnea, 35, 7-55.

OldField, S. (2008) Urban botanic gardens - benefiting people and biodiversity. BGjournal, 5, 2-3.

Pereira, T.S., Costa, M.L.M.N. \& Wyse Jackson, P. (eds) (2004) Plano de Ação para os Jardins Botânicos Brasileiros. Rede Brasileira de Jardins Botânicos, Rio de Janeiro, Brazil.

Pinheiro, M.H.O. (2000) Levantamento florístico e fitossociológico da floresta estacional semidecidual do Jardim Botânico Municipal de Bauru, São Paulo. MSc thesis. Universidade de Campinas, Brazil.

Pinheiro, M.H.O., Neto, L.C.A. \& Monteiro, R. (2006) Urban areas and isolated remnants of natural habitats: an action proposal for botanical gardens. Biodiversity and Conservation, 15, 2747-2764.

RAE, D. (2011) Fit for purpose: the importance of quality standards in the cultivation and use of live plant collections for conservation. Biodiversity and Conservation, 20, 241-258.

RBJB (Rede Brasileira de Jardins Botânicos) (2011) Jardins botânicos. Http://www.rbjb.org.br/jardins [accessed 4 October 2011].

Ribeiro, M.C., Metzger, J.P., Martensen, A.C., Ponzoni, F.J. \& Hirota, M.M. (2009) The Brazilian Atlantic Forest: how much is left, and how is the remaining forest distributed? Implications for conservation. Biological Conservation, 142, 1141-1153.

Rio Grande do Sul (2003) Decreto $n^{\circ} 42.099$ de 2002. Http://www. sema.rs.gov.br [accessed 7 December 2010].

Saiter, F.Z., Guilherme, F.A.G., Thomaz, L.D. \& Wendt, T. (2011) Tree changes in a mature rainforest with high diversity and endemism on the Brazilian coast. Biodiversity and Conservation, 20, 1921-1949.

São PAUlo (2004) Resolução SMA 48, de 21 de setembro de 2004. In Diário Oficial do Estado de São Paulo. 22 de setembro de 2004, Seção 1, pp. 26-29. São Paulo, Brazil.

SCBD (Secretariat of the Convention on Biological Diversity) (2010) Decision adopted by the Conference of the Parties to the Convention on Biological Diversity at its 1oth Meeting. $\mathrm{UNEP} / \mathrm{CBD} / \mathrm{COP} / \mathrm{DEC} / \mathrm{X} / 17$.

Silva, I.C. (2010) Caracterização fisionômica de fragmentos vegetacionais do distrito de Rubião Júnior, município de Botucatu, São Paulo. MSc thesis. Universidade Estadual Paulista, Brazil.

Sousa-Júnior, P.R.C. (2006) Estrutura da comunidade arbórea e da regeneração natural em um fragmento de floresta urbana, Recife-PE. MSc thesis. Universidade Federal Rural de Pernambuco, Recife, Brazil. SpeciesLink (2010) Http://splink.cria.org.br [accessed 15 August 2010]. Thomaz, L.D. \& Monteiro, R. (1997) Composição florística da Mata Atlântica de encosta da Estação Biológica de Santa Lúcia, município de Santa Teresa-ES. Boletim do Museu de Biologia Mello Leitão, 7, 3-48.

Ward, C.D., Parker, C.M. \& Shackleton, C.M. (2010) The use and appreciation of botanical gardens as urban green spaces in South Africa. Urban Forestry \& Urban Greening, 9, 49-55.

WeISER, V.L.B. (2007) Árvores, arbustos e trepadeiras do cerradão do Jardim Botânico Municipal de Bauru, SP. PhD thesis. Universidade Estadual de Campinas, Brazil.

Willis, C.K. \& Morkel, A. (2008) National Botanical Gardens: South Africa's urban conservation refuges. BGjournal, 5, 4-7.

Wyse Jackson, P. \& Kennedy, K. (2009) The Global Strategy for Plant Conservation: a challenge and opportunity for the international community. Trends in Plant Science, 14, 578-580.

Zappi, D.C., Forzza, R.C., Souza, V.C., Mansano, V.F. \& Morim, M.P. (2015) Epilogue. Rodriguésia, 66, 4-5.

\section{Biographical sketches}

Maria LÚcia M. N. Da Costa is interested in conservation policy and has been involved in activities aimed at strengthening capacity building for Brazilian botanic gardens. PETER WYSE JACKSON's research interests include plant conservation policies and practices, particularly as they relate to botanic gardens worldwide. RICARDO A. FERnANDES's research interests include biological databases and spatial analysis for conservation. Ariane L. Peixoto is interested in systematic and conservation studies of Phanerogams and in the history of botany. 